Smith, L. P. (1966). The English Language. 2nd ed. New York: Henry Holt and Company. Retrieved from https://gutenberg.ca/ebooks/smithlp-englishlanguage/smithlp-englishlanguage-00-h.html.

Spears, R. A. (2007). McGraw-Hill's Essential American Idioms Dictionary. New York; San Francisco: McGraw-Hill.

Siefring, J. (Ed.). (2004). The Oxford Dictionary of Idioms. 2nd Edition. Oxford: Oxford University Press. Retrieved from http://ngoaingu.vimaru.edu.vn/wp-content/uploads/documents/Oxford-Dictionary-ofIdioms-1.pdf.

\title{
THE MODELLING OF THE DOMAINS OF THE EXPRESSION OF THE CONCEPT OF LANGUAGE IN THE BRITISH PUBLICISTIC DISCOURSE ON THE BASIS OF THE CHI-SQUARE CRITERION МОДЕЛЮВАННЯ ДОМЕНІВ ВИРАЖЕННЯ КОНЦЕПТУ LANGUAGE В БРИТАНСЬКОМУ ПУБЛІЦИСТИЧНОМУ ДИСКУРСІ НА ОСНОВІ ПОКАЗНИКА $X^{2}$
}

\author{
Мирослава КОВАЛЮК \\ Чернівецький національний університет імені Юрія Федьковича \\ m.kovaliuk@chnu.edu.ua \\ ORCID ID 0000-0001-5972-2145
}

The article is devoted to the modelling of domains which express the concept of LANGUAGE in the British publicistic discourse on the basis of the $\chi^{2}$ criterion. A domain is a cognitive model that contains a set of features that are revealed when the concept name is combined with accompanying words. To determine the domains of the expression of the concept under study, the adjoining words (nouns, verbs, adjectives) are analyzed in one syntactic frame together with the nominative lexeme „language". Accompanying nouns, verbs and adjectives to the concept name of LANGUAGE are grouped by common thematic features and divided into lexical-semantic classes (LSCs), representing the spheres of concept expression: nouns constitute forty LSCs, verbs account for thirty-five LSCs, adjectives amount to twenty-six LSCs. The statistic-linguistic method of the $\chi^{2}$-test was employed to determine the lexical-semantic classes (LSCs) of adjoining lexemes associated with the name of the concept that are predominantly used in publicistic discourse and thus establish the most relevant areas of expression of the concept in the articles of the British publicistic discourse.

On the basis of the dominant LSCs in accordance with the $\chi^{2}$ criterion, domains of the expression of the concept of LANGUAGE were identified. Fourteen domains (,linguistic features of language”, „purity of speech”, „origin and territorial functioning of language”, „the existence of language and attitude to it”, ,people as native speakers”, ,education / science”, ,communication / emphatics in relation to language”, ,political and military spheres”, „modern technologies”, „religion”, „social spheres (Economics, Law, Sports) ”, „,art / mass media”, „time”, „body language”) were determined.The broadest domain is the domain of "linguistic features of language", which contains eight lexical-semantic classes. Such domains as „,body language”, ,the origin and territorial functioning of the language”, ,purity of speech”, ,people as native speakers”, ,social spheres (Economics, Law, Sports)”, ,education / science”, „modern technologies” are quite numerous in the discourse under study, since they make up six LSCs. The least used are the domains of ,art / mass media”, „time”, ,religion” (only two LSCs).

Key words: concept, domain, lexical-semantic class, adjoining words to the concept name, the statistic-linguistic method. 
Стаття присвячена моделюванню доменів вираження концепту LANGUAGE у британському публіцистичному дискурсі на основі показника $\chi^{2}$. Доменом називаємо когнітивну модель, яка містить сукупність ознак, які розкриваються при сполучуваності імені концепту із супровідними словами. Для визначення доменів вираження досліджуваного концепту проаналізовано супровідні лексеми (іменники, дієслова, прикметники) в одній синтаксичній рамці разом із номінативною лексемою іменником „language”. Супровідні іменники, дієслова й прикметники до імені концепту LANGUAGE погруповано за тематичною спільністю та поділено на лексико-семантичні класи (ЛСК), що репрезентують сфери вираження концепту: іменники - сорок ЛСК, дієслова - тридцять-п’ять, прикметники двадцять-шість. Використано лінгвостатистичний метод $\chi^{2}$-тесту для визначення тих лексикосемантичних класів супровідних до імені концепту лексем, що мають домінантний характер уживання в публіцистичному дискурсі і таким чином установлюють найактуальніші сфери вираження концепту в текстах британського публіцистичного дискурсу.

На основі домінантних ЛСК відповідно до показника $\chi^{2}$, змодельовано домени вираження концепту LANGUAGE. Зафіксовано чотирнадцять доменів у британському публіцистичному дискурсі (,лінгвістичні ознаки мови”, „чистота мови”, „походження й територіальне функціонування мови”, „існування мови та ставлення до неї”, „люди як носії мови”, „освіта / наука”, „спілкування / емфатика по відношенню до мови”, „політична й військова діяльність”, „сучасні технологіі”, „релігія”, „суспільна діяльність (економіка, юриспруденція, спорт), „мистецтво / ЗМI”, „час”, „парамова”). Найбільш широким доменом вважаємо домен „лінгвістичні ознаки мови”, який вміщає вісім лексико-семантичних класів. Домени „парамова”, „походження й територіальне функціонування мови”, „чистота мови”, „люди як носії мови”, „суспільна діяльність (економіка, юриспруденція, спорт)”, „освіта / наука”, „сучасні технології” є досить чисельними в досліджуваному дискурсі, оскільки складаються із шести ЛСК. До найменш наповнюваних доменів відносимо: домен „мистецтво / ЗМІ”, домен „час”, домен „релігія” (два ЛСК).

Ключові слова: концепт, домен, лексико-семантичний клас, супровідні слова, лінгвостатистичний метод.

Вступ. Концепт LANGUAGE, актуалізований у сучасному британському публіцистичному дискурсі, $є$ цілісною ментальною одиницею, в структурі якого відображена конфігурація його культурно значущих когнітивних ознак, що відбивають досвід використання мови суб'єктами мовлення крізь призму універсальних і культурно специфічних знань про мову. Зміст вербалізованого концепту LANGUAGE розкривається через домени його вираження у даному дискурсі.

Оскільки концепт є базовою одиницею когнітивної лінгвістики, основною одиницею представлення знань, то ряд праць провідних вітчизняних i закордонних лінгвістів (С. Г. Воркачов, В. І. Карасик, О. С. Кубрякова, В. А. Маслова, М. М. Полюжин, А. М. Приходько, О. О. Селіванова, та ін.) присвячена дослідженням концепту та когнітивним його моделям (Р. Ленекер і Дж. Лакофф, У. Крофт і А. Круз, Н. Г. Ссипенко, С. А. Жаботинська, А. П. Мартинюк). Актуальність нашого дослідження полягає у потребі детального аналізу і вивчення когнітивних моделей (доменів) концепту LANGUAGE, відповідає науковим інтересам до проблеми вивчення сфер актуалізації концепту. Залучення публіцистичного дискурсу до широкого лінгвокультурного контексту та використання лінгвостатистичних методів аналізу вербалізованого у ньому концепту відкриває новий ракурс вивчення 
актуалізації концепту в культурно маркованому контексті. Наукова новизна визначається встановленням сфер вираження концепту LANGUAGE в британському публіцистичному дискурсі з використанням $\chi^{2}$-тесту.

Метою статті є моделювати домени вираження втіленого у текстовому просторі концепту LANGUAGE. Основними завданнями $\epsilon$ : пояснити поняття концепту $\mathrm{i}$ домену $\mathrm{y}$ когнітивній лінгвістиці, провести частиномовну класифікацію супровідних лексем імені концепту LANGUAGE та їх поділ на лексико-семантичні класи (далі ЛСК); сформувати домени вираження концепту LANGUAGE на основі лінгвостатистичних методів у британському публіцистичному дискурсі, а саме критерію $\chi^{2}$.

Методи дослідження. У нашій статті ми використовуємо методику концептуального аналізу, що містить лінгвокультурний, когнітивно-дискурсний $\mathrm{i}$ лінгвостатистичний підходи. Когнітивно-дискурсний виявляе особливості актуалізації концепту LANGUAGE в публіцистичному дискурсі; лінгвокультурний підхід уможливлює встановлення культурних ознак концепту в британській спільноті; лінгвостатистичний підхід оперує точними даними про частотні характеристики лексем-вербалізаторів концепту і доменів його вираження.

Результати та обговорення. Концепт $\epsilon$ когнітивною категорією, поєднанням культурно значущих онтологічних, аксіологічних, модальних, функціональних характеристик, одиницею когнітивної лінгвістики та лінгвокультурології. Він притаманний ментальній сфері людини і концентрує визначені знання й емоції. Концепт - це ментальне утворення, що містить образи та поняття. Згідно з твердженням М. В. Нікітіна, складники значеннєвої структури концепту мають концептуальні зв'язки (Нікітін, 2009, с. 67), що є подібними до зв'язків між поняттями.

Вербальні засоби вираження концепту i їх сполучні характеристики формують концептуальну структуру концепту. Ім'я концепту разом із супровідними словами утворює домен вираження концепту. У нашому дослідженні ми опираємося на працю американського лінгвіста Р. Ленекера. Він доводить, що домени (когнітивні моделі) надають інформацію та формують знання про мову (Langacker, 1991). Домен містить сукупність ознак, які розкриваються при сполучуваності імені концепту із супровідними словами (Єсипенко, 2012). До супровідних слів А. Я. Шайкевич відносить слова, що часто зустрічаються в текстовому фрагменті в найближчому оточенні номінативної лексеми концепту і пов'язані одне з одним за змістом (Мунтян, 2016, с. 244).

Лексеми відіграють номінативну роль у вербалізації концепту. Для виокремлення лексико-семантичних класів супровідних слів до імені концепту LANGUAGE, ми визначили супровідні іменники, дієслова, прикметники до лексеми імені концепту проаналізованих фрагментів британського публіцистичного дискурсу. Ми класифікували лексеми-вербалізатори концепту в синтаксичній рамці одного речення за тематичною спільністю в лексикосемантичні класи, що репрезентують сфери вираження концепту (домени). Лексико-семантичний клас є сукупністю супровідних до імені концепту мовних одиниць, які розкривають одну спільну для них тему (Ковалюк, 2019, с. 22). 
На основі тематичного групування супровідних іменників до імені концепту LANGUAGE, ми поділили їх на 40 лексико-семантичних класів: назва мови: English, Latin; країна / національність: England, Sweden; професія / рід занять носіїв мови: politician, professor; сім'я / родина носіїв мови: mother, brother; час / вік: month, day; мова / мовна структура: language, lingo; економічна діяльність / робота: job, economy; державна сфера: campaign, candidate; навчання / освітня діяльність: teaching, training; наука / наукова діяльність: term, notion; відносини / ставлення: attitude, treatment; документи: constitution, bill; сфера вживання мови: culture, art; установа / місце використання мови: office, organization; емоційна сфера: feeling, emotion; артефакти / продукти діяльності: thing, photograph; подія / випадок: conference, event; міра / розмір: number, majority; тваринний / рослинний світ: animal, plant; мас-медіа / мистецтво: broadcasting, performance; мова тіла / частини тіла: body, gesture; ментальна сфера: thought, knowledge; мовленнєва діяльність: talk, conversation; батьківщина / нація: nation, population; люди / група людей: people, group; релігійна сфера: religion, prayer; абстрактні поняття: love, happiness; техніка / комп'ютер: cyberspace, software; транспорт / pyx: way, movement; їжа / напої: cuisine, breakfast; медична діяльність / фізіологічний стан людини: surgery, disease; спорт / гра: championship, game; пуризм: purism, purity; юридична сфера: crime, justice; продуктивна / деструктивна діяльність: development, increase, damage; мова знаків / звуки: sign, signal; мовна політика: impact, barrier; боротьба / військова діяльність: assault, attack; предмети одягу: jacket, lingerie; перебування / існування: presence, existence.

Ми виокремили 35 лексико-семантичних класів дісслів до імені концепту LANGUAGE, а саме: спілкування: to speak, to talk; відносини / ставлення: to treat, to protect; модальність: should, would; фізіологічна / фізична діяльність: to make, to do; ментальні діï: to think, to suggest; володіння / втрата: to possess, to own; придбання / збагачення: to bring, to take; рух: to come, to move; емоційний стан: to feel, to hope; перебування / існування: to be, to exist; пошук: to find, to search; зміна стану: to stop, to begin; розвиток, виникнення / створення: to emerge, to construct; здійснення навчальної / освітньої політики: to educate, to examine; наукова діяльність: to define, to investigate; дії мас-медіа: to broadcast, to film; юридична діяльність: to judge, to sentence; медична діяльність: to deteriorate, to check; дії тварини / рослини: to trap, to ape; боротьба / напад: to attack, to fight; здійснення мовної політики: to influence, to isolate; функціонування техніки / комп'ютерів: to decode, to install; економічна / фінансова діяльність: to cost, to pay; спортивна активність: to play, to win; контроль / влада: to control, to monitor; деструктивна діяльність: to destroy, to collapse; утілення мови тіла: to decipher, to mimic; звучання: to sound, to neigh; релігійна діяльність: to vow, to gather; військова діяльність: to war, to conquer; вимірювання: to measure, to shorten; очищення мови: to purify, to polish; здійснення державної політики: to vote, to commit; розташування: to arrange; структурування: to consist, to include.

Базуючись на фактичному вживанні супровідних атрибутивних лексем до імені концепту LANGUAGE в британському публіцистичному дискурсі поділяємо їх на 26 лексико-семантичних класів: опис емоційного стану: happy, angry; позитивна оцінка: great, good; негативна оцінка: bad, awful; опис (ознака) 
мови: common, compulsory; опис часових характеристик: annual, current; опис вікових характеристик: old, young; опис дії, виконаної над об'єктом: re-structured, separated; опис освітньої / наукової сфери: academic, educational; указівка назви / виду мови: Latin, Korean; указівка країни / національності: British, European; опис поведінки (рис характеру), ставлення / стосунків: aggressive, fierce; опис простору (місця) / розташування: far, rural; опис фізичного / фізіологічного стану об'єктів: alive, dead; опис кількості / розміру: double, few; опис мовленнєвої діяльності: conversational, communicative; опис державної сфери: official, political; опис зовнішності / параметрів: huge, high; опис мови тіла / мови звуків: facial, non-verbal; опис ментальної сфери: aware, capable; опис кольору: blue, colored; опис релігійної сфери: sectarian, divine; опис пуризму: clear, pure; опис pyxy: quick, hectic; опис нації / батьківщини: national, demographic; опис процесуальності: growing, evolving; опис техніки.

За допомогою лінгвостатистичних прийомів $\left(\chi^{2}\right.$-тест) визначається міра інтенсивності сполучення двох слів у тексті - на рівні семантичної сполучуваності („слово + підклас слів”) (Левицький, 2004). Когнітивносемантичний або асоціативний зв'язок супровідних слів існує при їх повторюваності. Використання $\chi^{2}$-тесту уможливлює виокремлення сфер вираження концепту LANGUAGE при статистичній обробці частот уживання ЛСК супровідних слів із номінативною лексемою концепту.

Найпоширенішою формулою для обчислення $\chi^{2} \epsilon$ :

$$
\chi^{2}=\sum \frac{(O-E)^{2}}{E},
$$

де $\mathrm{O}$ - фактично існуючі (емпіричні) величини; Е - теоретично очікувані; знак $\Sigma$ означає суму (Левицький, 2004, с. 35).

Наведемо приклад розрахунку $\chi^{2}$-тесту для перших одинадцяти ЛСК іменників, супровідних до імені концепту в Таблиці 1:

Величини $\chi^{2}$ для ЛСК іменників

Таблиия 1

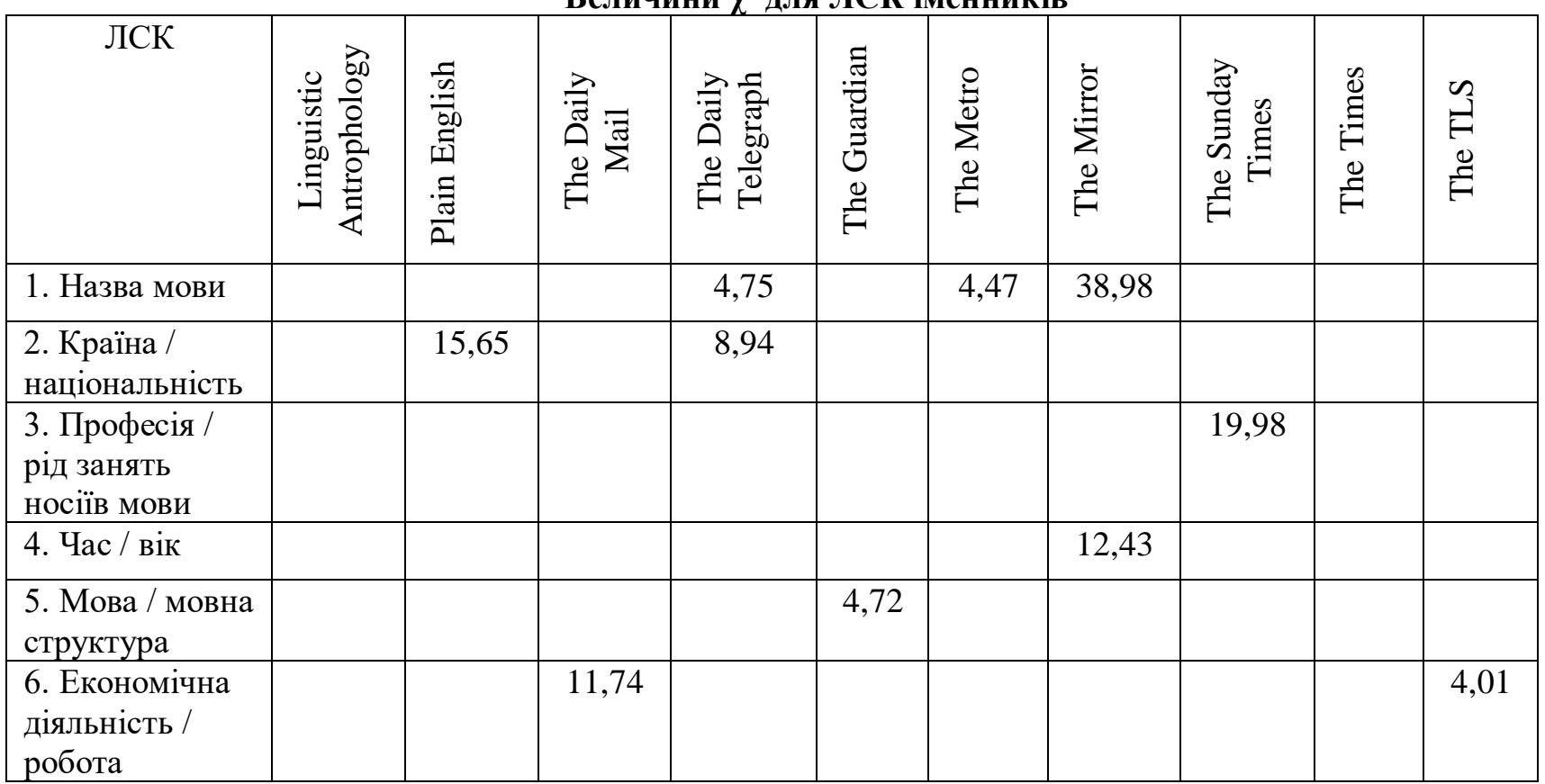




\begin{tabular}{|l|l|l|l|l|l|l|l|l|l|l|}
\hline $\begin{array}{l}\text { 7. Державна } \\
\text { сфера }\end{array}$ & & & 33,05 & & & & & & & \\
\hline $\begin{array}{l}\text { 8. Навчання / } \\
\text { освітня } \\
\text { діяльність }\end{array}$ & 12,57 & & 6,29 & & & & 7,51 & & & \\
\hline $\begin{array}{l}\text { 9. Наука / } \\
\text { наукова } \\
\text { діяльність }\end{array}$ & & & & & & & & & & 22,05 \\
\hline $\begin{array}{l}\text { 10. Відносини / } \\
\text { ставлення }\end{array}$ & & & 4,39 & & & & & & & \\
\hline
\end{tabular}

Перевищення показника $\chi^{2}$ вказує на перевагу емпіричного вживання певного ЛСК над теоретично очікуваним. Цим виокремлюємо селективність уживання того чи іншого ЛСК супровідних іменників, тобто важливість ЛСК для вербалізації концепту LANGUAGE. Як видно 3 Таблиці 1, для перших одинадцяти ЛСК іменників величина $\chi^{2}$ проявилася тричі для ЛСК „навчання / освітня діяльність”, а також для ЛСК „назва мови”, що підтверджує вибірковість цієї сфери вираження поняття мови, яка безпосередньо стосується іiї назви й освітньої сфери вживання мови. ЛСК постають своєрідними структурними елементами цілісних доменів, що вербалізуються в дискурсі. Для об'єднання ЛСК в домен їм має бути притаманна тематична спільність.

На основі отриманих селективних ЛСК супровідних іменників, дієслів та прикметників у десяти британських публіцистичних виданнях моделюємо сфери вираження концепту. Окрема сфера (домен) містить тематичні спільні ЛСК здебільшого трьох частин мови. Нами сформовано 14 доменів вираження концепту LANGUAGE, які подаємо нижче за ступенем їх наповнення:

1. домен „лінгвістичні ознаки мови” (виражений ЛСК іменників „назва мови”, „мова / мовна структура”, „сфера вживання мови”, дієслів „зміна стану”, „володіння / втрата”, „пошук”, прикметників „указівка назви / виду мови”, „опис процесуальності"), оскільки мова є компонентом життя людини:

„That since society is changing, it is only logical that the English language will change as well" (Plain English);

2. домен „парамова” (виражений іменниками „мова тіла / частини тіла”, „мова знаків / звуки”, дієсловами „звучання”, „медична діяльність”, прикметниками „опис мови тіла / мови звуків”, „опис фізичного / фізіологічного стану об'єктів”) вказує на вираження мови не лише вербальними, але й невербальними засобами:

,Body language was especially important to politicians because of the need to appear both dominant and likeable" (The Daily Telegraph).

3. домен „походження й територіальне функціонування мови” (ЛСК, утворені з іменників „країна / національність”, „тваринний / рослинний світ”, дієслів „розташування”, „вимірювання”, прикметників „указівка країни / національності”, „опис простору (місця) / розташування”), що виражає прив'язаність мови до певної території, де вона виникла чи нею розмовляють:

„Berber is most prominent in rural areas, and is considered the informal language of the home and of the street" (Plain English);

4. домен „чистота мови” (ЛСК з іменників „пуризм”, „мовна політика”, дієслів „очищення мови”, „здійснення мовної політики”, і прикметників „опис 
пуризму”, „негативна оцінка”), що вказує на актуальність збереження незасміченої форми мови:

„Urged native speakers to ,give up' their claims to be guardians of the purest form of the language" (The Guardian);

5. домен ,існування мови та ставлення до неї” (лексико-семантичні класи іменників „перебування / існування”, „відносини / ставлення”, і дієслів „перебування / існування”, „відносини / ставлення”) виражає релевантність існування мови в різних галузях і сферах, поєднює вираження ставлення до мови, і мову як інструмент вираження ставлення до чогось:

„In this marginalized state, many endangered languages continue to exist in specialized ,culture” realms” (Linguistic Antrophology);

6. домен ,люди як носії мови” (ЛСК з іменників ,професія / рід занять носіїв мови”, ,„юди / група людей”, „їжа / напої”, „предмети одягу”, прикметників „,опис зовнішності / параметрів”, „,опис нації / батьківщини”), це акцентує на важливості носіїв мови, що ії вживають і використовують зокрема в рамках своєї професії:

„English is the global language understood and spoken by 25 per cent of people on the planet" (The Metro);

7. домен „суспільна діяльність (економіка, юриспруденція, спорт)” (сформований на основі ЛСК іменників „юридична сфера”, „економічна діяльність / робота”, „спорт / гра”, дієслів ,юридична діяльність”, „,економічна / фінансова діяльність”, „рух”), що вказує на важливу роль мови для ведення судових процесів, у торговельній діяльності, а також на коректне їі вживання під час проведення спортивних змагань, ігор:

„, The language used in law is changing” (Plain English);

8. домен „освіта / наука” (ЛСК з іменників „навчання / освітня діяльність”, „наука / наукова діяльність”, „ментальна сфера”, дієслів ,здійснення навчальної / освітньої політики”, прикметників „опис освітньої / наукової сфери”, прикметників „опис ментальної сфери”), підкреслює неперервний зв’язок мови з когнітивною діяльністю й підтверджує актуальність та невід'ємність мови в цих сферах:

„The residential course comes amid major changes to language teaching, with all primary schools now required to teach a foreign language to pupils between the ages of seven and 11" (The Daily Mail);

9. домен „,ппілкування / емфатика по відношенню до мови” (виражений ЛСК з іменників „мовленнєва діяльність”, „емоційна сфера”, дієслів „спілкування”, „,емоційний стан”), що наголошує на важливості мови в процесі розмови та знаходженні взаєморозуміння:

„He loves the language but, as a writer, it does not belong to him” (Plain English);

10. домен ,політична й військова діяльність” (ЛСК з іменників ,державна сфера”, „боротьба / військова діяльність”, дієслів „військова діяльність”, прикметників „опис державної сфери”), що наголошує на необхідності мови для ведення переговорів, встановлення дипломатичних відносин, зокрема вирішення військових конфліктів:

,"The politics of language is destroying the language of politics” (The Times);

11. домен „сучасні технологіï” (ЛСК з іменників „техніка / комп’ютер”, „,артефакти / продукти діяльності”, „продуктивна / деструктивна діяльність”, 
дієслів „функціонування техніки / комп’ютерів”, „придбання / збагачення” та прикметників „опис техніки”), де мова набуває професійного забарвлення:

„Experts in Cobol computer language, first developed in the 1950s coming out of retirement as banks grapple with legislation" (The Daily Telegraph);

12. домен „мистецтво / ЗМІ” (ЛСК з іменників „мас-медіа / мистецтво” та дієслів „дії мас-медіа”) акцентує на релевантності мови в медійній сфері:

„They found that English language song lyrics are less positive than Russian literature, but cheerier than Korean film subtitles" (The Daily Telegraph);

13. домен „час” (сформований на основі ЛСК іменників „час / вік”, прикметників „опис часових характеристик”) описує існування й еволюцію мови в часовому вимірі :

,While building the basics of a conlang can take as little as a month or two, a really good language takes at least a few years" (The Daily Mail);

14. домен „релігія” (складають ЛСК 3 іменників „релігійна сфера”, прикметників „опис релігійної сфери”), що вказує на використання мови у веденні богослужінь, релігійних обрядів, молитов:

„Catholic church's English language liturgy changes today to unify translation of Mass around the world" (The TLS).

Отже, найбільш широким доменом із 8 лексико-семантичних класів $є$ домен „лінгвістичні ознаки мови”. Домени „парамова”, „походження й територіальне функціонування мови”, „чистота мови”, „люди як носії мови”, „суспільна діяльність (економіка, юриспруденція, спорт)”, „освіта / наука”, „сучасні технологіі” складаються із 6 ЛСК і є досить чисельними в досліджуваних дискурсах. Домени „існування мови та ставлення до неі”, „спілкування / емфатика по відношенню до мови”, „політична й військова діяльність” містять 4 ЛСК. До найменш наповнюваних доменів відносимо: домен „мистецтво / ЗМІ”, домен „час”, домен „релігія” (2 ЛСК).

Висновки. Отже, концепт LANGUAGE презентує універсальне явище, що має культурно марковані особливості актуалізації в британській лінгвокультурі. Знання про концепт LANGUAGE структуровані у вигляді доменів вираження вербалізованого концепту в публіцистичному дискурсі. Для визначення доменів вираження досліджуваного концепту ми проаналізували супровідні лексеми (іменники, дієслова, прикметники) в одній синтаксичній рамці разом із номінативною лексемою іменником „language”. Супровідні іменники, дієслова й прикметники до імені концепту LANGUAGE поділено на ЛСК: іменники - 40 ЛСК, дієслова - 35, прикметники - 26. Для достовірнішого аналізу частотності вживання ЛСК використано лінгвостатистичний метод $\chi^{2}$-тест. При виявленні $\chi^{2}$ для певного ЛСК в британському дискурсі констатуємо культурні особливості у втіленні концепту в публіцистичному дискурсі британської лінгвокультури, які свідчать про вагомість мови i мовленнєвої діяльності як невід'ємного компоненту життя і спілкування. Робиться акцент на прив'язаності мови до певної території, де вона виникла чи нею розмовляють, а також на вираженні мови не лише вербальними, але й невербальними засобами. Для британців мова тісно переплітається 3 освітою й наукою; вона $є$ інструментом ефективної політичної, економічної, спортивної й військової діяльності. Збереження 
незасміченої форми мови постає одним 3 актуальних питань, яке активно обговорюється в британській публіцистиці. Релевантність існування мови в різних галузях і сферах підкреслює важливість носіїв мови, що іï вживають i використовують зокрема в рамках своєї професії. Сучасні технології, де мова набуває професійного забарвлення є також важливою складовою життя сучасних британців. Вживання мови у богослужіннях, релігійних обрядах та в медійній сфері відносимо до найменш значущих сфер іiі використання у публіцистичному дискурсі. Подальші перспективи вбачаємо у висвітленні особливостей функціонування концепту LANGUAGE у різних типах дискурсу.

\section{Список літератури}

Єсипенко Н. Г. Базові англосаксонські лінгвокультурні концепти: когнітивний і квантитативний підходи (на матеріалі англомовної прози XVIII-XX століть) : дис. ... д-ра філол. наук : спец. 10.02.04. Чернівці, 2012. 457 с.

Ковалюк М. В. Лексико-семантичні класи прикметників-вербалізаторів концепту LANGUAGE в американському публіцистичному дискурсі. Науковий вісник Чернівецького університету : збірник наукових праць. Чернівці : Видавничий дім „РОДОВІД”, 2019. Вип. 810 : Германська філологія. С. 18-27.

Левицкий В. В. Квантитативные методы в лингвистике. Черновцы : Рута, 2004. 190 с.

Мунтян Л. В. Вербальне вираження концепту globalisation в мас-медійному дискурсі. Наукові записки Національного університету „Острозька академія”. Серія : Філологічна. 2016. Вип. 62. С. 243-245.

Никитин М. В. Основы лингвистической теории значения. [2-е изд.]. М. : Книжный дом „ЛИБРИКОМ”, 2009. 168 с.

Langacker R. W. Concept, Image and Symbol : the Cognitive Basis of Grammar. Berlin : Mouton de Gruyter, 1991. 395 p.

Linguistic Anthrophology. URL: http://linguisticanthropology.org/.

Plain English. URL: http://www.plainenglish.co.uk/.

The Daily Mail. URL: http://www.dailymail.co.uk/home/index.html/.

The Daily Telegraph. URL: http://www.telegraph.co.uk/.

The Guardian. URL: http://www.theguardian.com/uk/.

The Metro. URL: http://metro.co.uk/.

The Times. URL: http://www.thetimes.co.uk/tto/news/.

TLS (The Times Literary Supplement). URL: http://www.the-tls.co.uk/tls/.

\section{References}

Yesypenko, N. H. (2012). Bazovi anhlosaksonski linhvokulturni kontsepty: kohnityvnyi i kvantytatyvnyi pidkhody (na materiali anhlomovnoi prozy XVIII-XX stolit) [Basic Anglo-Saxon linguistic and cultural concepts: cognitive and quantitative approaches (based on English prose of the XVIII-XX centuries)] : dys. ... d-ra filol. nauk : spets. 10.02.04. Chernivtsi.

Kovaliuk, M. V. (2019). Leksyko-semantychni klasy prykmetnykiv-verbalizatoriv kontseptu LANGUAGE $\mathrm{v}$ amerykanskomu publitsystychnomu dyskursi [The lexical-semantic classes of adjectives verbalizing the concept of LANGUAGE in American publicistic discourse]. Naukovyi visnyk Chernivetskoho universytetu : zbirnyk naukovykh prats. Chernivtsi: Vydavnychyi dim „RODOVID”. Vyp. 810 : Hermanska filolohiia, 18-27.

Levitskiy, V. V. (2004). Kvantitativnye metody v lingvistike [Quantitative methods in Linguistics]. Chernovtsy : Ruta.

Muntian, L. V. (2016). Verbalne vyrazhennia kontseptu globalisation v mas-mediinomu dyskursi [Verbal expression of concept globalisation in mass media discourse ]. Naukovi zapysky Natsionalnoho universytetu ,Ostrozka akademiia”. Seriia: Filolohichna. Vyp. 62, 243-245.

Nikitin, M. V. (2009). Osnovy lingvisticheskoy teorii znacheniya [Fundamentals of linguistic theory of meaning]. [2-e izd.]. M.: Knizhnyy dom „LIBRIKOM”.

Langacker, R. W. (1991). Concept, Image and Symbol : the Cognitive Basis of Grammar. Berlin : Mouton de Gruyter.

Linguistic Anthrophology. URL: http://linguisticanthropology.org/.

Plain English. URL: http://www.plainenglish.co.uk/. 
The Daily Mail. URL: http://www.dailymail.co.uk/home/index.html/.

The Daily Telegraph. URL: http://www.telegraph.co.uk/.

The Guardian. URL: http://www.theguardian.com/uk/.

The Metro. URL: http://metro.co.uk/.

The Times. URL: http://www.thetimes.co.uk/tto/news/.

TLS (The Times Literary Supplement). URL: http://www.the-tls.co.uk/tls/.

УДК811.11’372

\title{
CONCEPTSYSTEM OF MODERN ENGLISH TOURISM ADVERTISING DISCOURSE КОНЦЕПТОСИСТЕМА СУЧАСНОГО АНГЛОМОВНОГО ТУРИСТИЧНОГО РЕКЛАМНОГО ДИСКУРСУ
}

\author{
Тетяна КОЛІСНИЧЕНКО, Тетяна КОРОПАТНІЦЬКА \\ Чернівецький національний університет імені Юрія Федьковича \\ t.kolisnichenko@chnu.edu.ua, t.koropatnicka@chnu.edu.ua \\ ORCID ID 0000-0001-5312-0522, ORCID ID 0000-0002-8076-075X
}

The present research focuses on analysis of the tourism advertising discourse as an independent institutional type of discourse. The correlation of visual and textual means in tourism advertising discourse appeals to recipient's positive emotions that allows the addresser to control postcommunicative actions of the addressee. The topicality of the research lies in the necessity to present the discursive framework of the modern English tourism advertising discourse. The end-goal is to define main components of the cognitive domain of the English speakers as a structural framework of knowledge and ideas concerning tourism and advertising spheres and present them as a cognitive map.

The goal can be achieved through the tasks aimed at defining and analysis of the typical and statistically significant correlations between autochthons that form the framework of the discourse and at cognitive mapping of the modern English tourism advertising discourse. The method of introspection helps to identify the national mentality peculiarities and reveal the discursive-significant implicit meaning and in our research, it is used to detect the main autochthons correlations (subordination, following-up, causing and exception). Cognitive mapping of the modern English tourism advertising discourse where autochthons and correlations between them are graphically fixed helps to specify the peculiarities of the cognitive mechanism of the analyzed discourse. The cognitive mechanism is characterized by a sound framework with situational awareness, discursive strategy and chronotope features. The interconnections presented in the cognitive map delineate the typical images of the English speakers about the advertised destination in the tourism sphere that are modelled in the consciousness as the components of the concept sphere of the modern English tourism advertising discourse.

Key words: discourse, tourism advertising discourse, cognitive map, concept, autochthon, interconcept correlation, introspection, domain.

У фокусі дослідження знаходиться туристичний рекламний дискурс, що потрактовується як самостійний інституційний вид дискурсу, в якому поєднання візуальних та текстових засобів спрямоване на апелювання до позитивних емоційних факторів реципієнтів 3 кінцевою метою контролю та коригування посткомунікативних дій адресата, необхідних та вигідних адресантові. Актуальність дослідження визначається необхідністю представлення дискурсотвірного каркасу сучасного англомовного туристичного рекламного дискурсу. Мета дослідження полягає у спробі виокремити основні елементи колективного когнітивного 